\title{
The Application of International Accounting Standard's Requirements No. (20) in Jordanian Chemical Detergents Industry Companies
}

\author{
Dr. Jamal Adel Al-Sharairi (Corresponding author) \\ Associate Professor, Accounting Department, Faculty of Finance and Business Administration \\ University of Al Al-Bayt \\ P.O.Box 1195, Tareq 11947, Amman, Jordan \\ Tel: 96-27-7764-2444Ｅ-mail: jamalsharairi@yahoo.com
}

Dr. Majed A. Alsharayri

Associate Professor - Accounting Department

Faculty of planning and Management, Balqaa' Applied University, Jordan

Tel: 96-27-7720-6638Ｅ-mail: majedsharay@hotmail.com

Received: October 30, 2011

Accepted: November 24, 2011

Published: March 1, 2012

doi:10.5539/ijef.v4n3p152

URL: http://dx.doi.org/10.5539/ijef.v4n3p152

\begin{abstract}
The study aimed at identifying the extent to which Jordanian chemical detergents industry companies applying the requirements of international accounting standard No. (20). A questionnaire has been designed for this purpose and distributed to the external auditors of these companies of (50) auditors / questionnaire, (30) questionnaires were recovered and were suitable for analysis, with recovery rate reached to $(60 \%)$. Resolution data was analyzed using (SPSS), and a number of statistical techniques through descriptive statistics, arithmetic means, standard deviations and percentages. The results of the study showed that Jordanian chemical detergents industry companies do not apply the requirements of international accounting standard No. (20), and there are difficulties that limit the application of the mentioned standard in a high degree. The study recommended urging Jordanian chemical detergents industry companies to implement the requirements of international accounting standard No. (20), in addition to helping Jordanian chemical detergents industry companies to reduce the difficulties of application of international accounting standard No, (20) and treated them radically.
\end{abstract}

Keywords: International accounting standards, Chemical detergents, Jordanian companies, Detergents industry, High degree

\section{Introduction}

Governments had contributed in the rapid developments that have taken place in the world and occur recently in most fields in our industrial and economic lives, through their support represented in grants and government assistance to support development sectors including the industrial sector which considered the most important, this matter required that industrial companies will include the balance and the values of these grants in their financial statements by generally accepted accounting treatments, which brought by international accounting standards, where International Accounting System allocated number (20) for this purpose.

In spite of the different accounting systems in the industrial sectors from other sectors and the existence of financial and accounting legislations governing in each country, there must be a role for the International Accounting Standards (IAS) in the treatment and implementation.

And here comes this study to shed light on the Jordanian chemical detergents industry companies and their application of Accounting Standard No. (20), that consists of accounting, government grants and disclosure of government assistance, which is given either in the form of cash to protect the environment, for example, or that the government gives the company a land in a remote area to revive it in the future.

\section{Study Problem}

The problem of the study represents in the need to know the extent to which Jordanian chemical detergents industry companies implement the International Accounting Standard No. (20), the international accounting standard is 
specified by the developed countries to comply with legislations, by-laws and laws in these countries, it is easy to apply them in those developed countries, but on the local level, they can have a conflict with local legislations and laws. The problem of the study can be formulated through the following main question: Are Jordanian chemical detergents industry companies implement International Accounting Standard No. (20), the following questions come out from this question:

1. Do Jordanian chemical detergents industry companies recognize the government grants?

2. Do the government grants display in the financial statements of the Jordanian chemical detergents industry companies?

3. Do Jordanian chemical detergents industry companies re-pay the government grants?

4. Do Jordanian chemical detergents industry companies recognize the government assistance?

5. Do Jordanian chemical detergents industry companies disclose according to the requirements of Accounting Standard No. (20)?

6. Are there difficulties that limit the application of International Accounting Standard No. (20) in the Jordanian chemical detergents industry companies?

\section{Study Objectives}

The study aims at identifying the extent of the application of Jordanian chemical detergents industry companies to the requirements of International Accounting Standard No. (20), through the following objectives:

1. Recognition of the extent of Jordanian chemical detergents industry companies of the government grants.

2. Showing the extent of government grants in financial statements of Jordanian chemical detergents industry companies.

3. Recognition of the extent of re-payment of government grants by Jordanian chemical detergents industry companies.

4. Recognition of the extent of Jordanian chemical detergents industry companies of government assistance.

5. The extent of disclosure of Jordanian chemical detergents industry companies in accordance with Accounting Standard No. (20).

6. Indicating the difficulties that limit the application of the requirements of International Accounting Standard (20) in Jordanian chemical detergents industry companies.

\section{Significance of The Study}

The significance of the study came in the importance of the application of Jordanian industry companies to the requirements of International Accounting Standard No. (20) in general, and Jordanian chemical detergents industry companies in particular, the fact that the government often supports the industrial sectors, including chemical companies in the form of grants and assistance, for the difficulty of working in them and the negative impacts of this industry, where it is assumed by these companies to deal with these grants and government assistance in accounting way, either under the local financial legislations or under International Accounting Standard No. (20). The importance of this study that it is the first study talks about the International Accounting Standard No. (20) at the local and Arab level to the knowledge of the researcher.

\section{Hypotheses of The Study}

5.1 First Hypothesis: Jordanian Chemical Detergents Industry Companies do not Apply International Accounting Standard No. (20).

\section{The following sub-hypotheses ramify from the first hypothesis:}

1. Jordanian chemical detergents industry companies do not recognize government grants.

2. Government grants do not display in financial lists of Jordanian chemical detergents industry companies.

3. Government grants do not re-pay in Jordanian chemical detergents industry companies.

4. Jordanian chemical detergents industry companies do not recognize government assistance.

5. Accounting disclosure for government grants is not disclosed in accordance with International Accounting Standard No. (20). 


\subsection{Second Hypothesis: There are no Difficulties that Limit the Application of the International Accounting Standard No. (20) Requirements in Jordanian Chemical Detergents Industry Companies.}

\section{Previous Studies}

The study of (Al-Otaibi, 2010) aimed at identifying the extent to which Kuwaiti contribution companies meet the requirements of: measurement, disclosure provisions assets and potential liabilities under International Accounting Standard No. (37). In order to achieve the objectives of the study, a questionnaire was designed for this purpose and distributed to financial managers and their assistants, questionnaires which were subject to analysis were (162). The study found commitment of Kuwaiti companies with the requirements of disclosure and measurement, with percentages of $73 \%, 72.8 \%$, and $58.6 \%$, respectively, for provisions and contingent liabilities and possible assets. The study recommended the need to increase compliance with the requirements of measurement and disclosure of the listed items, as well as the need for rehabilitation and training of financial managers and encourage them to obtain professional, local and international certification.

The study of (Al-Sriheen, 2009) aimed at identifying the extent of the commitment of the Jordanian public shareholding companies with the disclosure's requirements for inventories under IAS No. (2) from the point of view of the external auditor. A questionnaire was designed for this purpose and distributed to (112) external auditors. The study showed that there is a commitment to a fair degree phase to disclose the value of the stock and the disclosure of accounting policies adopted in measuring inventories, the study recommended to provide adequate information and more disclosure for the goods in the road and to be placed in a separate item.

The study of (Al-Alimat, 2007) aimed at identifying the extent of the respondents' support in the Jordanian petrochemical industry contribution companies to factors that influencing accounting disclosure of the costs of social responsibility in the financial statements of their companies and the disclosure of that in accounting. The study showed that the petrochemical companies of Jordan contribute highly in many social fields such as disclosure of the costs of providing public safety conditions for their workers, health insurance for workers, reduce pollution, get rid of it safely, companies' possession of the establishment licenses that consistent with environmental matters, disclosure of contributions and grants provided to members of the community and the recycling of production's output to reduce the environmental damage because of their interest in the long run with their reputation. The study recommended the necessity for petrochemical companies of Jordan to focus on the establishment of educational, recreational and health centers so that the members of the society can reach to the public welfare and improve their living conditions.

The study of (Bamzahm, 2003) aimed at analyzing and test the impact of accounting disclosure of social environmental of Jordanian public shareholding companies that are trading shares on Amman financial market on the investment decisions by recognizing the importance of information disclosure provided by the social environment in the companies to take investment decisions, the results showed the following: The disclosure of social environmental performance disclosure was not satisfactory, what is disclosed is not more than a qualitative and descriptive disclosure. An accounting disclosure of the social environmental performance still needs a lot of development.

The study of (Al-Khatib, 2002) aimed at collecting necessary information and data regarding the basis of presentation of financial statements in Jordanian public shareholding companies on the principle of disclosure for public purposes and to ensure comparability of the private financial statements concerning the facilities for the previous years, and by what this principle required explanation that the users of financial statements interest in for the decision-making process, especially when the disclosure of financial data is sufficient in the attached financial statements. Where the study relied on the deductive approach, which is based on the study of financial reports of the Jordanian Industrial Corporations in 1999, and to study the level of disclosure of the information in the financial statements in the specified period, and its variability from year to year, and the factors affecting the level of disclosure of the company under study.

\section{Materials and Methods}

Analytical approach was used in this study depending on primary and secondary data for the statistical analysis, they were collected through a questionnaire, which is designed according to the nature of the study problem. T-Test was used for testing hypotheses results using simple and multiple regressions. the researchers extracted the arithmetic means and standard deviations for ratings on the questionnaire paragraphs

\subsection{Study Determinants}

This study was conducted on Jordanian chemical detergents industry companies within the Greater Amman Municipality, which Jordanian government do not have any shares in these companies, as noted by the International Accounting Standard No. (20) "does not apply to: government participation in ownership of the entity" (IASB, 2007) 
(IFRS, 2011), and thus companies owned by the Jordanian government, whether in whole or in possession of a partial contribution were excluded. There are also no studies on this subject about Jordan to the knowledge of the researcher.

\subsection{Population and Sample of the Study}

The population of the study consists of Jordanians Chartered Accountants (external auditors) certified and practitioners of the auditing profession, they have been counted and numbered to (255) auditors. The authors selected of them all auditors who audit in Jordanian chemical detergents industry companies as a study sample, there number were (50) auditors, where the questionnaire was distributed to the entire sample. The distributed questionnaires were (50) and the recovered were (30) questionnaires that are valid for analysis, with a percentage recovery of $(60 \%)$ as shown in Table (1) .

\section{Statistical Analysis}

A field for answers has been identified, giving five options for responses to each question to know the opinion of respondents about the application of the Standard requirements No. (20), its levels were set through the use of five Likert scale as shown in the table (2).

Based on this, the arithmetic means of the study, will be dealt with to interpret the data as follows:

(1 -2.49) means low degree, (2.50 -3.49) implies a medium degree and (3.5-5) means a high degree as shown in Table (3) .

Central tendency measures were used as arithmetic mean, standard deviation, frequencies and percentages for the purposes of description of study data and analysis it, in addition to statistical tests for a (T) test.

For the purposes of analysis, the following statistical methods were used:

\subsection{Descriptive Analysis}

This analysis adopted the arithmetic mean, standard deviation and percentages.

- To test the study tool and its reliability in testing hypotheses and to achieve the objectives of the study, an internal consistency measure Cronbach's Alpha was used; to measure the credibility of the sample of the study answers on the questions from the questionnaire and (Sekaran, 2003) explains the internal coefficient reliability of the responses that the statistically significant accepted value for this measure are (\%) or more.

The results of calculation of this factor showed that consistency in the paragraphs were very high, which confirms the reliability of the questionnaire to test hypotheses, as illustrated in the table (4),

the values of reliability coefficient (internal consistency) reached for the tool (0.825), which is high and suitable value for the purposes of the study, it is noted that Cronbach's alpha value for the recognition of government grants field amounted to (0.740), for the presentation of government grants the value was $(0.861)$, the re-payment of government grants $(0.727)$, the recognition of government assistance $(0.815)$ and the disclosure requirements for government assistance (0.846) and the difficulties of applying the standard " 20 " $(0.766)$ where all values reflect the high persistence and sufficient for the purposes of this study.

\subsection{Data Analysis Related to Demographic Characteristics of Respondents}

Distribution of respondents by demographic characteristics of the study sample is shown in the table (5):

* It is noted from the table that the majority of the study sample in the Gender variable are males, as it accounted for $(80 \%)$ of the members of the study sample, while the percentage of females were $(20 \%)$ of the members of the study sample, this reflects the nature of profession or job.

* It is noted from the table that more members of the study sample were within the age group of (35-45) reaching percentage of (40\%) followed by age group of (25-35 years) with a percentage of (30\%), the age group category (45 and over) occupied the last rank with a percentage of $(10 \%)$ which showed of the presence of an inconsistency between the age and experience of members of the study sample.

* It is noted from the mentioned previously table that more members of the study sample between those who experience (10-5 years) accounted for (40\%), then those with experience of (15-10 years) were (30\%), which indicates the presence of consistency between the age and years of job experience, which is a positive indication, thus enhancing the scientific capacity to understand questions and answer of the questionnaire properly, which help in strengthening for the judgment of the study hypotheses.

\subsection{Data Analysis Related to The Study Fields}

In order to describe the application requirements of the IAS No. (20), the researchers extracted the arithmetic means and standard deviations for the members of the sample estimations on the questionnaire paragraphs. 
The arithmetic mean, standard deviations and percentages values for each paragraph of the recognition of government grants as shown in Table(6). Paragraphs $(1,9,11)$ occupied the first rank, with an arithmetic mean of (3.27), which was the highest means, while paragraph (4), occupied the second rank, with an arithmetic mean of (3.10), paragraphs (2) and (3) came last, with an arithmetic mean of each reached (2.83), the overall field of the arithmetic mean / recognition of government grants were (3.03), the mean value of this shows that the government grants have achieved fair degree according to the used scale.

For each paragraph of presenting government grants shown in Table(7), paragraph (12) has occupied the first rank, with an arithmetic mean of (3.27), which is the highest means, paragraph (13) has occupied the second rank, with an arithmetic mean of (3.23), paragraph (19) came last, with an arithmetic mean of (2.97). The total field of the arithmetic mean / Presenting Government Grants reached (3.08) the value of this mean shows that presenting the government grants had achieved at medium degree.

For each paragraph of the re-payment of government grants which illustrated in Table(8), paragraph (20) has occupied the first rank, with arithmetic mean of (3.30), which is the highest means, paragraph (21) occupied the second rank, with arithmetic mean of (3.03), paragraph (23) came last, with arithmetic mean of (2.93). The total field of the arithmetic mean /re-payment of government grants reached (3.04) the average value shows that the repayment of government grants have been achieved in a medium degree.

The recognition of government assistance shown in Table(9), paragraph (26) has occupied the first rank, with an arithmetic mean of (3.73), which is the highest means, paragraph (32) occupied the second rank, with an arithmetic mean of (3.23), paragraph (28) came last, with an arithmetic mean of (3.03). The total field of the arithmetic mean / Recognition of government assistance reached (3.18); the average value shows that recognition of government assistance has achieved a medium degree.

The accounting disclosure for government grants shown in Table (10), paragraph (33) has occupied the first rank, with an arithmetic mean of (3.37), which is the highest means, paragraph (35) occupied the second rank, with an arithmetic mean of (3.23), paragraph (34) came last, with an arithmetic mean of (3.13). The total field of the arithmetic mean / Disclosure of the accounting for government grants reached (3.24), the average value shows that the accounting disclosure for government grants has achieved a medium degree.

The difficulties of applying the standard (20), paragraph (39) has occupied the first rank, with an arithmetic mean of (4.40), which is the highest means, paragraph (40) occupied the second rank, with an arithmetic mean of (4.37), paragraph (36) came last, with an arithmetic mean of (4.20). The total field of the arithmetic mean / Difficulties in the application of criterion (20) reached (4.31), the value of this mean shows that the difficulties of applying the standard (20) has achieved in a high degree as shown in Table(11).

\subsection{The Results and Testing Hypotheses of the Study Using Multiple Regressions}

For the purpose of testing hypotheses of the study which were verified and accepted or rejected by a (T) test, the default center was adopted (3) for this purpose, table no. (12) shows the results of multiple linear regression test for the extent of the application of IAS (20).

\section{We can note from table no. (12) the following:}

1. Calculated (T) value related to the sub-hypothesis (1) amounted to (0.50) with the significance level of $(0.614)$, which is less than indexed (T) that amounted of (2.04), the null hypothesis are accepted if the calculated (T) value is less than indexed $(\mathrm{T})$, null is refused if the calculated $(\mathrm{T})$ is greater than indexed $(\mathrm{T})$, based on the above sub-hypothesis (1) is accepted, which states: " Jordanian chemical detergents industry companies do not recognize government grants".

2. The value of calculated (T) for the sub-hypothesis no. (2) amounted to (1.13) with a significance level of (0.268), which is less than indexed value of (2.04), and through this comparison we accept the hypothesis which states that: " Government grants do not display lists in financial companies in Jordanian chemical detergents industry companies".

3. It was found that the calculated ( $\mathrm{T}$ ) value for sub-hypothesis no. (3) amounted to (0.79) with a significance level of (0.433), which is less than its indexed value which is (2.04). Therefore, and based on the basis of acceptance of previous hypotheses, sub-hypothesis no. (3) are accepted, which states that: " Government grants do not be re-paid off in Jordanian chemical detergents industry companies".

4. Also it has shown that the calculated (T) value for sub-hypothesis no. (4) amounted to (2.81) with a significance level of (0.009) which is greater than its indexed value which is amounted (2.04). Therefore, and based on the basis of acceptance of previous hypotheses, hypothesis no. (4) are rejected, which states that: " Jordanian chemical detergents industry companies do not recognize government assistances". 
5. As the calculated (T) value for sub-hypothesis no. (5) has reached (2.58) with a significance level of (0.015), which is less than indexed value which is amounted (2.04). Therefore, and based on a rejection of the previous hypotheses, hypothesis no. (5) are accepted, which states that: "It does not make an accounting disclose for government grants in accordance with International Accounting Standard No. (20)".

As for the calculated $(\mathrm{T})$ value for the main hypothesis, this refers to "Jordanian chemical detergents industry companies do not apply International Accounting Standard No. (20)" has reached (7.84) with a significance level of (0.000), which is larger than the indexed $(\mathrm{T})$ value which amounted (2.04), this means a rejection of this hypothesis and thus conclude that Jordanian chemical detergents industry companies do not apply the requirements of international Accounting Standard no. (20).

Table no. (13) shows that the value of calculated (T) related to the difficulties in the application of International Accounting Standard No. (20) in Jordanian chemical detergents industry companies amounted to (30.11) with a significance level of (0.000), which is greater than indexed value (2.04) and where calculated (T) value is larger than the indexed, so the second hypothesis is rejected, which states that: There are no difficulties that limit the application of International Accounting Standard No. (20), in the sense that there are difficulties that limit the application of the requirements of International Accounting Standard No. (20) in Jordanian chemical detergents industry companies and that is confirmed by the value of high arithmetic mean which amounted (4.31), which represents a high degree of difficulty.

\section{Discussions}

By analyzing the data and testing hypotheses and discussed it in the previous chapter, the study found:

Firstly: Although there is a limited application to the requirements of Accounting Standard No. (20) However, Jordanian chemical detergents industry companies in general do not apply the requirements of International Accounting Standard No. (20), this is indicated by the statistical results and as follows in descending order in terms of lack of application:

- The recognition of government grants are the least applied in Jordanian chemical detergents industry companies.

- Then the re-payment of government grants, as it also does not apply in Jordanian chemical detergents industry companies which higher a little bet.

- Followed by government grants in the financial statements, where there is not also application to this requirement.

- The requirement to recognize government assistance, where it is applied in a medium degree.

- Finally, accounting disclosure requirement for government grants which is the most applied, but in a medium degree.

Secondly: With regard to the difficulties that limit Jordanian chemical detergents industry companies from applying IAS, there is a high degree of difficulty, which is arranged as follows in terms of higher difficulty:

There is no support from the administration for the application of International Accounting Standard No. (20) in those companies.

- The nature of the activity in Jordanian chemical detergents industry companies has a significant role in the non-implementation.

- Lack of qualified personnel that limit at the high degree of application of standard no. (20).

- The lack of obligation to apply the standard has a big role in reducing the application.

- Finally, understanding and awareness difficulties of the requirements of International Accounting Standard No. (20) that limit the application.

\section{0 . Conclusions}

Through the findings of the study, the study recommends the following:

Jordanian chemical detergents industry companies urged to implement the requirements of International Accounting Standard No. (20) and more particularly the following:

- The need for applying the recognition requirement of government grants

- The need for applying the re-pay of government grants requirement

- The need for applying presenting government grants requirement

- The need for increasing the application of the recognition of government assistance requirement 
- The need for increasing the application of accounting disclosure requirement

Helping Jordanian chemical detergents industry companies to find out the difficulties of reducing the application of International Accounting Standard no. (20) and treated it radically, by the following:

- The need for adequate support by the administration to apply the international standard no. (20)

- Work to provide a suitable environment between the nature of chemical detergents companies' activity and the process of applying the standard no. (20)

- The obligation to provide by the concerned parties and those on the application of international accounting standards.

- Increase the provision of qualified accountants and auditors in Jordanian chemical detergents industry companies.

- Work on training and rehabilitation, held an introduction courses about the International Accounting Standards in general, international accounting no. (20) In particular, for the most understanding and awareness of the international accounting standards.

The need for greater focusing by accounting departments in the Jordanian universities to expand into the details of the International Accounting Standards in the study plans.

\section{References}

Al-Alimat, Nofan. (2007). Factors influencing accounting disclosure of the costs of social responsibility in the financial statements of Jordanian petrochemical industry contribution companies. Unpublished Master Thesis, University of Al Al-Bayt, Jordan.

Al-Sriheen, D. (2009). The commitment of the Jordanian public shareholding companies disclosure requirements for inventories under IAS No. (2) From the viewpoint of the external auditor Unpublished Master Thesis, University of Al Al-Bayt.

Abu, N., \& H. Mohammed. (2009). Accounting Standards and International Financial Reporting-the theoretical and scientific aspects National Library, with support from the Deanship of Scientific Research at the University of Jordan, the second floor.

Abu, N., H. Mohammed. (2010). Accounting Standards and International Financial Reporting-the theoretical and scientific aspects National Library, with support from the Deanship of Scientific Research at the University of Jordan, the third floor.

Al-Otaibi, M.K. (2010). Companies and their commitment to the measurement and disclosure requirements of ... Unpublished Master Thesis, University of Al Al-Bayt, Jordan.

Al-Khatib, K. (2002). Accounting disclosure in the financial reports of jordanian public shareholding companies under the international accounting standard (1). University Damascus J., 18: 2.

Bamzahm, F. (2004). The environmental impact of accounting disclosure on investment decisions in the Jordanian public shareholding companies. Unpublished Master Thesis, Al Al-Bayt University, Jordan.

IASB. (2007). International Financial Reporting Standards. IASCF, London UK.

IFRS. (2011). International Financial Reporting Standards Part A, 1 of January IAS 20, A635, London UK.

Sekaran,U. (2003). Research Method for Business: A Skill Building Approach, 7th Edn. John Wiley and Sons, New York.

\section{Appendices}

Table 1. Number of questionnaires distributed, recovered and approved in the analysis

\begin{tabular}{|l|c|c|}
\hline \multicolumn{1}{|c|}{ Statement } & Number & Percentage \\
\hline Distributed Questionnaires & 50 & $100 \%$ \\
\hline Recovered Questionnaires Appropriate for Analysis & 30 & $60 \%$ \\
\hline
\end{tabular}

Table 2. Answers of the Study Sample Degrees According to Five Likert Scale

\begin{tabular}{|c|c|c|c|c|}
\hline Strongly Agree & Agree & Moderately Agree & Disagree & Strongly Disagree \\
\hline 5 & 4 & 3 & 2 & 1 \\
\hline
\end{tabular}


Table 3. Data Interpretation into Three Degrees

\begin{tabular}{|c|c|c|}
\hline Highly Applied & Moderately Applied & Low Applied \\
\hline 3.5 and above & $2.5-3.49$ & $1-2.49$ \\
\hline
\end{tabular}

Table 4. Consistency Factors in Cronbach's Alpha Manner for the Internal Consistency of the Study Fields

\begin{tabular}{|l|c|c|}
\hline \multicolumn{1}{|c|}{ Field } & Number of Questions & Coefficient Alpha Value \\
\hline Government Grants' Recognition & 11 & 0.740 \\
\hline Presentation of Government Grants & 8 & 0.861 \\
\hline Repayment of Government Grants & 6 & 0.727 \\
\hline Recognition of Government Assistance & 7 & 0.815 \\
\hline Accounting Disclosure for Government Grants & 3 & 0.846 \\
\hline Difficulties in Applying the Standard No. (20) & 5 & 0.766 \\
\hline Overall Field & 40 & 0.825 \\
\hline
\end{tabular}

Table 5. Demographic characteristics of study sample

\begin{tabular}{|l|l|c|c|}
\hline \multicolumn{1}{|c|}{ Variable } & \multicolumn{1}{|c|}{ Category } & Repetitions & Percentage \\
\hline \multirow{2}{*}{ Gender } & Male & 24 & $80 \%$ \\
\cline { 2 - 4 } & Female & 6 & $20 \%$ \\
\hline \multirow{2}{*}{ Total } & & 30 & $100 \%$ \\
\hline \multirow{3}{*}{ Age } & Less than 25 years & 6 & $20 \%$ \\
\cline { 2 - 4 } & From 25 years to less than 35 years & 9 & $30 \%$ \\
\cline { 2 - 4 } & From 35 years to less than 45 years & 12 & $40 \%$ \\
\cline { 2 - 4 } & 45 years and over & 3 & $10 \%$ \\
\hline \multirow{2}{*}{ Total } & & 30 & $100 \%$ \\
\hline \multirow{2}{*}{ Experiences } & Less than 5 years & 3 & $10 \%$ \\
\cline { 2 - 4 } & From 5 years and less than 10 years & 9 & $40 \%$ \\
\cline { 2 - 4 } & From 10 years and less than 15 years & 6 & $30 \%$ \\
\cline { 2 - 4 } & From 15 years and above & 30 & $20 \%$ \\
\hline \multirow{2}{*}{ Total } & & 92 & $100 \%$ \\
\hline
\end{tabular}


Table 6. Arithmetic means and standard deviations for each paragraph of the first field: Recognition of government grants $(\mathrm{N}=30)$

\begin{tabular}{|c|c|c|c|c|c|}
\hline No. & Recognition of government grants & Mean & $\begin{array}{c}\text { Standard } \\
\text { Deviation }\end{array}$ & Percentages $\%$ & Sort \\
\hline 1 & $\begin{array}{l}\text { The company applies the recognition of government grants conditions, including non-monetary grants at } \\
\text { fair and assessed value, so that the two conditions were available together, namely: the entity will meet } \\
\text { the requirements for the grant and a reasonable assurance for the actual receipt of the grant. }\end{array}$ & 3.27 & 0.69 & 65.33 & 1 \\
\hline 2 & $\begin{array}{l}\text { Actual receipt of the grant does not necessarily mean that the entity will meet the special conditions of the } \\
\text { grant. }\end{array}$ & 2.83 & 0.79 & 56.67 & 10 \\
\hline 3 & $\begin{array}{l}\text { Recognition treatment is not affected by how to receive the value of the grant, which the treatment is not } \\
\text { different weather it was received in cash or the value of the grant is deducted from governmental } \\
\text { obligations owed by the entity. }\end{array}$ & 2.83 & 0.65 & 56.67 & 10 \\
\hline 4 & $\begin{array}{l}\text { Government grants are recognized as income during the time period necessary to match them with the } \\
\text { costs of fulfilling the terms of the grant, on a regular basis, and the grants should not be added directly to } \\
\text { shareholders. }\end{array}$ & 3.07 & 0.64 & 61.33 & 5 \\
\hline 5 & $\begin{array}{l}\text { The grant is recognized as an income through the distribution of the value of the grant on periods of time } \\
\text { necessary to fulfill the terms of the grant, as to use the costs incurred by the entity to meet the terms of the } \\
\text { grant as the basis for distribution to the time periods for implementation in the event that the government } \\
\text { grant does not involve the provision of assets which is not depreciated, such as cash grants or reduce the } \\
\text { government's commitment to the enterprise. }\end{array}$ & 2.97 & 0.81 & 59.33 & 7 \\
\hline 6 & $\begin{array}{l}\text { In the event that the grant is already capable of depreciation, in that case the grant is recognized as income } \\
\text { during the period of time consumed by those assets with a depreciation of asset rates in each period. For } \\
\text { example, a private hospital has an ambulance donated by the government entity; in this case the value of } \\
\text { the car is distributed on the estimated useful life of the asset according to the used depreciation method. }\end{array}$ & 2.90 & 0.76 & 58.00 & 8 \\
\hline 7 & $\begin{array}{l}\text { The grants that include the presence of more than one condition that the entity must achieved are } \\
\text { recognized, some of these conditions may require special costs and specific period of time to fulfill, } \\
\text { which requires in this case the analysis of the value of the grant to parts and to link the recognition of each } \\
\text { part of the costs which will be incurred to meet the related requirement. }\end{array}$ & 2.87 & 0.57 & 57.33 & 9 \\
\hline 8 & $\begin{array}{l}\text { Received government grants are recognized as compensation for the entity for actually suffered expenses } \\
\text { or losses or when the purpose of the grant is to provide immediate financial support for the entity without } \\
\text { incurring future costs related to implement the grant conditions, in this case, the value of the grant is } \\
\text { recognized as an income for the period which becomes receivable. }\end{array}$ & 3.10 & 0.61 & 62.00 & 4 \\
\hline 9 & $\begin{array}{l}\text { The grants provided by the government for some of the entities are recognized as compensation for losses } \\
\text { incurred in the past because of the work within a remote area or as a result that these entities are } \\
\text { negatively affected by the decisions of government. }\end{array}$ & 3.27 & 0.83 & 65.33 & 1 \\
\hline 10 & $\begin{array}{l}\text { The accounting treatment for non-monetary grants such as the government give a land or building in a } \\
\text { remote area, register it at fair value for the asset is cash }\end{array}$ & 3.00 & 0.53 & 60.00 & 6 \\
\hline 11 & $\begin{array}{l}\text { The accounting treatment for non-monetary grants such as the government give a land or building in a } \\
\text { remote area, both the asset and the grant is fixed "nominal amount" symbolic, the amount of one dinars } \\
\text { for example. }\end{array}$ & 3.27 & 0.52 & 65.33 & 1 \\
\hline & Overall field / Recognition of Government Grants & 3.03 & 0.36 & 60.67 & \\
\hline
\end{tabular}


Table 7. Arithmetic means and standard deviations for each paragraph of the second /field: Presenting government grants $(\mathrm{N}=30)$

\begin{tabular}{|c|c|c|c|c|c|}
\hline No. & Presenting Government Grants & Mean & $\begin{array}{l}\text { Standard } \\
\text { Deviation }\end{array}$ & Percentages \% & Sort \\
\hline 12 & $\begin{array}{l}\text { Government grants related to assets, including non-monetary grants at fair value that are installed in the } \\
\text { general budget are presented as deferred income, then being recognized later as income in a specific } \\
\text { way according to the costs incurred in fulfilling the terms of the grant. }\end{array}$ & 3.27 & 0.69 & 65.33 & 1 \\
\hline 13 & $\begin{array}{l}\text { Government grants related to assets, including non-monetary grants at fair value that are installed in the } \\
\text { general budget are presented in deducting the amount of the related grant value of assets to reach to the } \\
\text { carrying value (net) of the asset. }\end{array}$ & 3.23 & 0.73 & 64.67 & 2 \\
\hline 14 & $\begin{array}{l}\text { Government grants related to income as credited in the income statement are presented either separately } \\
\text { or under the general heading "like other income". }\end{array}$ & y 3.07 & 0.74 & 61.33 & 4 \\
\hline 15 & Government grants related to income are presented in subtracting the grant of the associated expenses. & 2.90 & 0.61 & 58.00 & 8 \\
\hline 16 & $\begin{array}{l}\text { Government grants related to assets are presented in the statement of cash flows when the receipt of } \\
\text { grants related to assets in cash. }\end{array}$ & 3.10 & 0.61 & 62.00 & 3 \\
\hline 17 & $\begin{array}{l}\text { Received cash flows are shown within the department of investment activities in the statement of cash } \\
\text { flows, in addition to that there will also be a result of external cash flows resulted in purchasing the asset } \\
\text { stipulating in terms of the grant. }\end{array}$ & 3.07 & 0.64 & 61.33 & 4 \\
\hline 18 & Received flows and foreign payments are shown separately and not shown in net by offsetting. & 3.00 & 0.59 & 60.00 & 6 \\
\hline 19 & $\begin{array}{l}\text { Receipts are shown separately from payments, regardless whether the devaluation of the original grant } \\
\text { or not when viewed in the budget. }\end{array}$ & 2.97 & 0.72 & 59.33 & 7 \\
\hline Ove & erall field / Presenting Government Grants & 3.08 & 0.36 & 61.50 & \\
\hline
\end{tabular}

Table 8. Arithmetic means and standard deviations for each paragraph of the third field: Repayment of government grants $(\mathrm{N}=30)$

\begin{tabular}{|l|l|c|c|c|}
\hline No. & \multicolumn{1}{|c|}{ Repayment of government grants } & Mean & $\begin{array}{c}\text { Standard } \\
\text { Deviation }\end{array}$ & Percentages \% \\
\hline 20 & $\begin{array}{l}\text { Breaching the terms of the grant so that the grant becomes available for re-payment, it shall } \\
\text { be treated as a change in accounting estimates under IAS No. (8) and is accountable } \\
\text { prospectively through the income statement. }\end{array}$ & 3.30 & 0.47 & 66.00 \\
\hline 21 & $\begin{array}{l}\text { A grant related to income is re-paid, in this case, the use of the balance amount of the } \\
\text { unamortized grant is followed (deferred income grant which its balance is credited), if any, to } \\
\text { cover the re-paid amounts. }\end{array}$ & 3.03 & 0.67 & 60.67 \\
\hline 22 & $\begin{array}{l}\text { A grant related to income is re-paid, in this case if the required re-paid amount exceeds the } \\
\text { balance of deferred income grant, it must recognize the amounts remaining from the re-paid } \\
\text { grant as an expense. In case there was no credit balance of deferred grant income, the full } \\
\text { re-paid amounts of the grant are recognized as an expense. }\end{array}$ & 2.97 & 0.49 & 59.33 \\
\hline 23 & $\begin{array}{l}\text { Re-paid grants to the donors related to assets are being treated by increasing the book value } \\
\text { (registered) of the asset related to the grant, this method is used in presenting the grant when } \\
\text { obtained as a reduction of the asset value. }\end{array}$ & 2.93 & 5 \\
\hline 24 & $\begin{array}{l}\text { Re-paid grants to the donors related to assets are being treated by reducing the balance of the } \\
\text { re-paid deferred income, this method is used in case of selection of presenting the grant as } \\
\text { deferred income. }\end{array}$ & 3.00 & 0.78 & 58.67 \\
\hline 25 & $\begin{array}{l}\text { It is directly recognized as an expense the aggregate additional accumulated depreciation, } \\
\text { which will be recognized to date as an expense in the absence of the grant. }\end{array}$ & 3.03 & 6 \\
\hline Total field / Re-payment of Government Grants & 6.56 & 60.67 \\
\hline
\end{tabular}


Table 9. Arithmetic means and standard deviations for each paragraph of the fourth field: Recognition of government assistance $(\mathrm{N}=30)$

\begin{tabular}{|c|c|c|c|c|c|}
\hline No. & Recognition of government assistance & Mean & $\begin{array}{c}\text { Standard } \\
\text { Deviation }\end{array}$ & Percentages \% & Sort \\
\hline 26 & We can distinct between government grants and government assistances in the company. & 3.73 & 0.64 & 74.67 & 1 \\
\hline 27 & $\begin{array}{l}\text { Technical free or almost free consultancy or processes with the government are recognized } \\
\text { and cannot be distinguished from normal business operations of the entity, such as allocating a } \\
\text { portion of the state purchases of some goods and services to the entity. }\end{array}$ & 3.10 & 0.61 & 62.00 & 4 \\
\hline 28 & $\begin{array}{l}\text { Technical free or almost free advice are disclosed or an operations with the government that } \\
\text { cannot be distinguished from normal business operations of the entity, such as allocating a } \\
\text { portion of the state purchases of some goods and services to the entity. }\end{array}$ & 3.03 & 0.67 & 60.67 & 6 \\
\hline 29 & $\begin{array}{l}\text { Interest-free loans or low interest rates that the government donates as assistances are } \\
\text { recognized. }\end{array}$ & 3.07 & 0.58 & 61.33 & 5 \\
\hline 30 & $\begin{array}{l}\text { Interest-free loans or low interest rates for that the government donates as assistances are } \\
\text { disclosed. }\end{array}$ & 3.13 & 0.57 & 62.67 & 3 \\
\hline 31 & $\begin{array}{l}\text { Companies recognize the indirect assistances representing in the government's provision of } \\
\text { infrastructure through the improvement of transport networks, telecommunications and water. }\end{array}$ & 2.97 & 0.72 & 59.33 & 7 \\
\hline 32 & $\begin{array}{l}\text { Companies disclose the indirect assistances representing in the government's provision of } \\
\text { infrastructure through the improvement of transport networks, telecommunications and water. }\end{array}$ & 3.23 & 0.68 & 64.67 & 2 \\
\hline Tot & al field / Recognition of Government Assistance & 3.18 & 0.35 & 63.62 & \\
\hline
\end{tabular}

Table 10. Arithmetic means and standard deviations for each paragraph of the fifth field: Accounting disclosure of government grants $(\mathrm{N}=30)$

\begin{tabular}{|l|l|l|l|l|l|}
\hline No. & \multicolumn{1}{|c|}{ Accounting disclosure of government grants } & Mean & \multicolumn{1}{|c|}{$\begin{array}{c}\text { Standard } \\
\text { Deviation }\end{array}$} & Percentages \% & Sort \\
\hline 33 & $\begin{array}{l}\text { The adopted accounting policy for government grants are disclosed, including the } \\
\text { view of government grants that have been followed in the financial statements. }\end{array}$ & 3.37 & 0.72 & 67.33 & 1 \\
\hline 34 & $\begin{array}{l}\text { The nature and extent of government grants that have been obtained and recognized } \\
\text { and government assistance that benefited from established are being disclosed. }\end{array}$ & 3.13 & 0.57 & 62.67 & 3 \\
\hline 35 & $\begin{array}{l}\text { Conditions that the entity do not met and other emergency events related to } \\
\text { government assistance that have been recognized are being disclosed. }\end{array}$ & 3.23 & 0.73 & 64.67 & 2 \\
\hline Total field / Accounting Disclosure for Government Grants & 3.24 & 0.52 & 64.89 & \\
\hline
\end{tabular}

Table 11. Arithmetic means and standard deviations for each paragraph of the fifth field: Difficulties in applying the standard (20) $(\mathrm{N}=30)$

\begin{tabular}{|l|l|c|c|c|c|}
\hline No. & \multicolumn{1}{|c|}{ Difficulties in the Application of Accounting Standard No. (20) } & Mean & $\begin{array}{c}\text { Standard } \\
\text { deviation }\end{array}$ & Percentages \% & Sort \\
\hline 36 & Difficulties in understanding and awareness of the IAS (20). & 4.20 & 0.41 & 84.00 & 5 \\
\hline 37 & Lack of qualified personnel will limit the application of Accounting Standard No. (20). & 4.30 & 0.53 & 86.00 & 3 \\
\hline 38 & Non-compulsory application of IAS (20). & 4.30 & 0.53 & 86.00 & 3 \\
\hline 39 & Lack of support from management for the application of Accounting Standard No. (20). & 4.40 & 0.62 & 88.00 & 1 \\
\hline 40 & $\begin{array}{l}\text { The difficulty of applying International Accounting Standard No. (20) due to the nature } \\
\text { of the company's activity. }\end{array}$ & 4.37 & 0.61 & 87.33 & 2 \\
\hline \multicolumn{2}{|l|}{ Total field / Difficulties Applying the Standard (20) } & 4.31 & 0.24 & 86.27 & \\
\hline
\end{tabular}


Table 12. The results of T-test to test the hypothesis of the major study and their sub-hypotheses

\begin{tabular}{|c|c|c|c|c|c|c|}
\hline Hypothesis Field & Mean & $\begin{array}{l}\text { Standard } \\
\text { Deviation }\end{array}$ & Calculated T & Tabulated T & Sig & $\begin{array}{c}\text { Null Hypothesis } \\
\text { Result }\end{array}$ \\
\hline Sub-hypothesis no. (1): Recognition of government grants. & 3.03 & 0.36 & 0.50 & 2.04 & 0.614 & Acceptance \\
\hline $\begin{array}{l}\text { Sub-hypothesis no. (2): Presenting the government grants in } \\
\text { financial statements. }\end{array}$ & 3.08 & 0.36 & 1.13 & 2.04 & 0.268 & Acceptance \\
\hline Sub-hypothesis no. (3): Re-payment of government grants. & 3.04 & 0.31 & 0.79 & 2.04 & 0.433 & Acceptance \\
\hline Sub-hypothesis no. (4): Recognition of government assistances. & 3.18 & 0.35 & 2.81 & 2.04 & $* 0.009$ & Rejection \\
\hline $\begin{array}{l}\text { Sub-hypothesis no. (5): Accounting disclosure for government } \\
\text { grants. }\end{array}$ & 3.24 & 0.52 & 2.58 & 2.04 & $* 0.015$ & Rejection \\
\hline $\begin{array}{l}\text { The first major hypothesis: Application of International } \\
\text { Accounting Standard No. (20). }\end{array}$ & 3.32 & 0.22 & 7.84 & 2.04 & $* 0.000$ & Rejection \\
\hline
\end{tabular}

Table 13. T-test results to examine the second major hypothesis of the study

\begin{tabular}{|l|c|c|c|c|c|c|}
\hline \multicolumn{1}{|c|}{ Hypothesis Field } & Mean & $\begin{array}{c}\text { Standard } \\
\text { Deviation }\end{array}$ & $\begin{array}{c}\text { Calculated } \\
\mathrm{T}\end{array}$ & $\begin{array}{c}\text { Indexed } \\
\mathrm{T}\end{array}$ & $\begin{array}{c}\text { Sig } \\
\text { Null Hypothesis } \\
\text { Result }\end{array}$ \\
\hline $\begin{array}{l}\text { The second major hypothesis: Difficulties in the application of } \\
\text { Accounting Standard No. (20). }\end{array}$ & 4.31 & 0.24 & 30.11 & 2.04 & $* 0.000$ & Rejection \\
\hline
\end{tabular}

